\title{
Catecholamine-induced stimulation of testosterone production by Leydig cells from fetal mouse testis
}

\author{
G. Pointis and M. T. Latreille \\ INSERM U.166, Groupe de Recherches sur l'Endocrinologie de la Reproduction, \\ Maternité Baudelocque, 123 Bld de Port-Royal, 75014 Paris, France
}

\begin{abstract}
Summary. In contrast to the strong stimulation of testosterone production by hCG, L-isoproterenol had little effect on freshly isolated Leydig cells from 18-day-old mouse fetuses. However, the ability of fetal Leydig cells to respond to L-isoproterenol exposure increased during culture $(0-24 \mathrm{~h})$. The response of the cultured cells to Lisoproterenol was dose-dependent with an $\mathrm{ED}_{50}$ at $2 \times 10^{-7} \mathrm{M}$. Adrenaline and noradrenaline at a concentration of $10^{-5} \mathrm{M}$ also increased testosterone production by cultured fetal Leydig cells. DL-Propranolol, a $\beta$-antagonist, inhibited L-isoproterenolstimulated testosterone production in a dose-dependent manner, while phentolamine, an $\alpha$-adrenergic antagonist, had no effect. These results suggest that catecholamines may play an essential role in the control of testicular steroidogenesis during fetal development.
\end{abstract}

\section{Introduction}

A direct involvement of catecholamines in adult testicular function has been suggested by results from experiments with isolated interstitial cells. Isoproterenol, adrenaline and noradrenaline have been shown to stimulate both cyclic AMP accumulation and testosterone production (Cooke et al., 1982; Moger et al., 1982) by interacting with specific receptors located on the Leydig cell surface (Poyet \& Labrie, 1983; Anakwe et al., 1985). Such a stimulatory effect was, however, only observed in cultured Leydig cells and not in freshly isolated cells or whole decapsulated testis. During fetal development, catecholamines are present in high concentrations in the amniotic fluid and fetal circulation (Zuspan et al., 1974; Ben-Jonathan \& Maxson, 1978). In addition, maximal levels of biogenic amines have been detected in the testis of neonatal rats of 1-day of age as compared with prepubertal and adult animals (Zieher et al., 1971). We have reported that isoproterenol, a $\beta$-adrenergic agonist, is able to stimulate testosterone production by mouse fetal Leydig cells in primary culture (Pointis \& Latreille, 1986), and that fetal Leydig cell steroidogenesis could be modulated by catecholamines. In the present study the dose-response to isoproterenol and the acquisition of catecholamine responsiveness during the culture period were determined. In addition we examined the effect of adrenaline, noradrenaline, propranolol (a $\beta$-adrenergic antagonist) and phentolamine (an $\alpha$-adrenergic antagonist) on testosterone production by fetal Leydig cells.

\section{Materials and Methods}

Chemicals. hCG (2nd IS for chorionic gonadotrophin for bioassay, 2180 i.u./mg) was provided by the National Institute for Biological Standards and Control (London, U.K.). L-Isoproterenol, L-adrenaline, L-noradrenaline, DL-propranolol, 3-isobutyl-1-methylxanthine (MIX) and ascorbic acid were commercial preparations from Sigma Chemical Co. (St Louis, MO, U.S.A.). Phentolamine was a gift from Ciba-Geigy A.G. (Basel, Switzerland). N-2 hydroxyethylpiperazine- $N^{\prime}$-2-ethanesulphonic acid (Hepes) and bovine serum albumin (BSA) were purchased from Eurobio (Paris, France) and ICN Pharmaceuticals Inc. (Cleveland, OH, U.S.A.), respectively. All other chemicals were from Difco Laboratories (Detroit, MI, U.S.A.). 
Leydig cell preparation. Leydig cells were isolated from 18-day-old fetal Swiss mice by mechanical dissection and collagenase digestion as previously reported (Pointis et al., 1984). Cell viability was tested by Trypan blue dye exclusion and Leydig cells were identified by staining for $3 \beta$-hydroxysteroid dehydrogenase (3 $\beta$-HSD) using a procedure previously described (Pointis \& Latreille, 1985). Leydig cells were cultured in Medium 199 supplemented with $15 \mathrm{~mm}$-Hepes, $0.1 \% \mathrm{BSA}, 0.5 \mathrm{~g}$ glucose $/ 1,100 \mathrm{u}$ penicillin $/ \mathrm{ml}$ and $100 \mu \mathrm{g}$ streptomycin $/ \mathrm{ml}$ in Falcon tissue-culture dishes (diameter $15 \mathrm{~mm}$ ) at a density of $1-5 \times 10^{4} 3 \beta$-HSD-positive cells/dish. At different times after the start of the culture $(0,6,12,24 \mathrm{~h})$ the culture medium was replaced with fresh medium modified to contain $0 \cdot 1 \mathrm{~mm}-\mathrm{MIX}$, a phosphodiesterase inhibitor which increases endogenous levels of cAMP, and $0.1 \mathrm{mM}$-ascorbic acid to reduce breakdown of catecholamines. L-Isoproterenol, L-adrenaline, L-noradrenaline, DL-propranolol and phentolamine were dissolved in this medium and added to the culture dishes as $10 \mu \mathrm{l}$ at the concentration required. The hCG was used at a concentration which gave maximal testosterone response as previously determined (Pointis \& Latreille, 1985). The cells were subsequently incubated for $3 \mathrm{~h}$ at $37^{\circ} \mathrm{C}$ in an atmosphere of $95 \%$ air, $5 \% \mathrm{CO}_{2}$. At the end of the incubation, media were removed by aspiration, centrifuged at $3000 \mathrm{~g}$ for $20 \mathrm{~min}$ and stored at $-30^{\circ} \mathrm{C}$ for measurement of testosterone.

Testosterone assay. Testosterone concentrations in the culture media were assayed after appropriate dilutions by a specific radioimmunoassay as previously described (Pointis et al., 1984) and expressed as ng/10 ${ }^{4} 3 \beta-\mathrm{HSD}_{\text {-positive }}$ cells. The specific antibody to testosterone was purchased from Institut Pasteur Production, Paris, and $\left[1,2,6,7-{ }^{3} \mathrm{H}\right]$ testosterone (sp. act. $92 \mathrm{Ci} / \mathrm{mmol}$ ) was from the Radiochemical Centre, Amersham, Bucks, U.K. The sensitivity of the assay was $7 \mathrm{pg} / \mathrm{sample}$. The inter- and intra-assay coefficients of variation for the assay were $<8 \%$. Cross-reaction with $5 \alpha$-dihydrotestosterone was $36 \%$ but was $<2 \%$ with other steroid hormones. Since the testosterone values were comparable with or without celite chromatography (Pointis \& Mahoudeau, 1974), this step was omitted.

Statistical analysis. Results were analysed by analysis of variance (ANOVA), and the significance of differences between treatment group means was determined by Duncan's new multiple range test.

\section{Results}

\section{Catecholamine stimulation of testosterone production}

In agreement with our previous findings (Pointis \& Latreille, 1986), isoproterenol, a nonselective $\beta$-agonist, stimulated testosterone production when added to fetal Leydig cells on Day 2 of culture at concentrations ranging from $10^{-9}$ to $10^{-5} \mathrm{M}$ (Fig. 1). A dose-response curve for isoproterenol stimulation was obtained with half-maximum stimulation value estimated at about $2 \times$ $10^{-7} \mathrm{M}$. Testosterone production reached maximal values in the presence of $10^{-5} \mathrm{M}$-isoproterenol. Adrenaline and noradrenaline, at a concentration of $10^{-5} \mathrm{M}$, also had a stimulatory effect on testosterone production. The mean \pm s.e.m. $(n=3)$ levels of testosterone in the presence of these agents were respectively $3.40 \pm 0.25$ and $2 \cdot 70 \pm 0.08 \mathrm{ng} / 10^{4} 3 \beta$-HSD-positive cells. These levels were significantly higher than the control values of $1 \cdot 33 \pm 0 \cdot 15 \mathrm{ng} / 10^{4} 3 \beta$-HSD-positive cells $(P<0.01)$. Figure 2 shows that treatment of control cells with a maximal stimulating dose of hCG $(100 \mathrm{mi} . \mathrm{u} . / \mathrm{ml})$ brought about a substantial increase in testosterone accumulation $(P<0.001)$. No additive effect of isoproterenol and hCG could be detected for any concentrations of the $\beta$-adrenergic agent tested $\left(10^{-9}\right.$ to $\left.10^{-5} \mathrm{M}\right)$.

\section{Acquisition of catecholamine responsiveness during culture period}

The response of fetal Leydig cells to isoproterenol, characterized as percentage of basal testosterone production (stimulated - basal $/$ basal) $\times 100$ ) ) to eliminate differences in basal production on different days of the experiment, appeared to be time-dependent over the period studied: values were $23 \cdot 7 \pm 5 \cdot 3$ ( 4 replicates), $53 \pm 2(2), 72 \cdot 7 \pm 3 \cdot 7(2), 87 \cdot 7 \pm 12 \cdot 5$ (4) at $0,6,12$ and $24 \mathrm{~h}$ respectively. Statistical analysis of the data revealed a significant effect of the time in culture on the acute response to isoprotenerol $(\mathrm{F}(3,8)=10 \cdot 29, P<0 \cdot 01)$. Freshly isolated fetal Leydig cells responded to isoproterenol with only a slight increase in testosterone production while a maximal dose of hCG $(100 \mathrm{mi} . \mathrm{u} . / \mathrm{ml})$ induced a 6 -fold increase (control: $1.00 \pm 0.05 \mathrm{ng}$ testosterone $/ 10^{4} 3 \beta$-HSD-positive cells; hCG-stimulated cells: $6.05 \pm 0.15 \mathrm{ng}$ testosterone $/ 10^{4} 3 \beta$-HSD-positive cells). The stimulatory effect of isoproterenol on testosterone production increased gradually thereafter with a maximal response observed after $24 \mathrm{~h}$ of culture. 


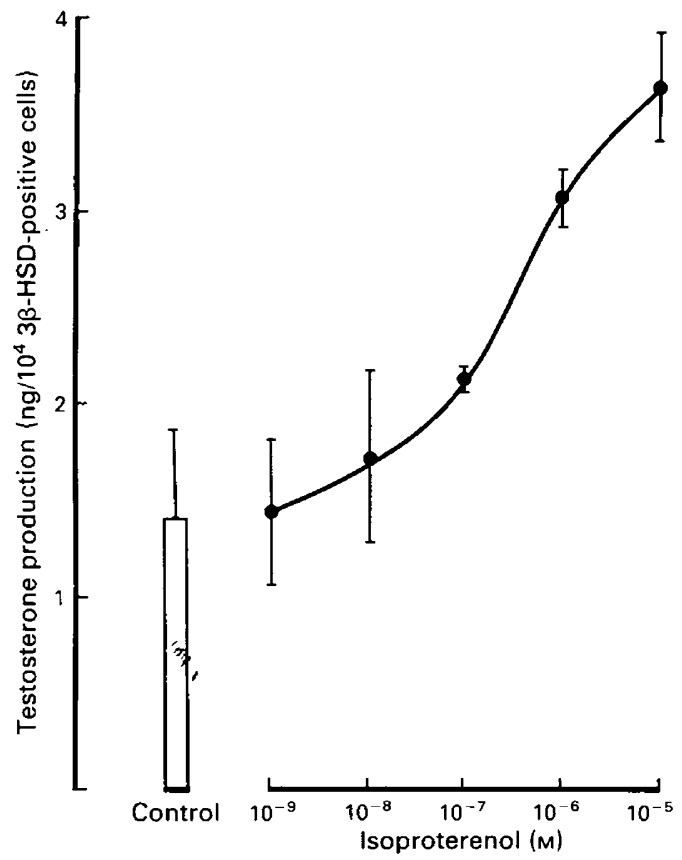

Fig. 1. Isoproterenol stimulation of testosterone production by fetal mouse Leydig cells in primary culture. Testosterone was measured in the medium after $3 \mathrm{~h}$ incubation in the presence of increasing concentrations of isoproterenol on Day 2 of culture. Control refers to testosterone production by unstimulated cells. Vertical lines indicate the s.e.m. of triplicate cultures. Results are representative of 2 experiments.

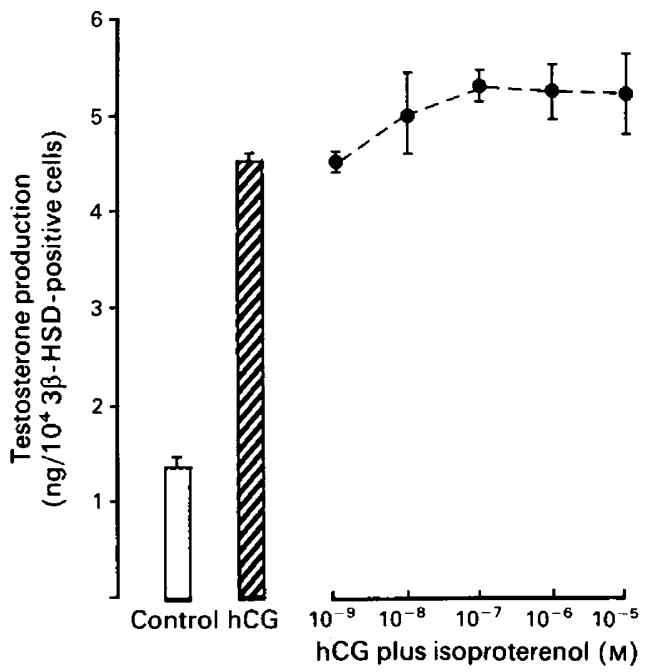

Fig. 2. Effect of concomitant addition of hCG and isoproterenol to the culture medium of fetal mouse Leydig cells. On Day 2 of culture, fetal Leydig cells were incubated for $3 \mathrm{~h}$ in the presence of increasing doses of isoproterenol plus or minus a maximal dose of hCG $(100 \mathrm{mi} . \mathrm{u} . / \mathrm{ml})$. Control refers to testosterone production by unstimulated cells. Results are the mean \pm s.e.m. of triplicate cultures and are representative of 3 experiments. 


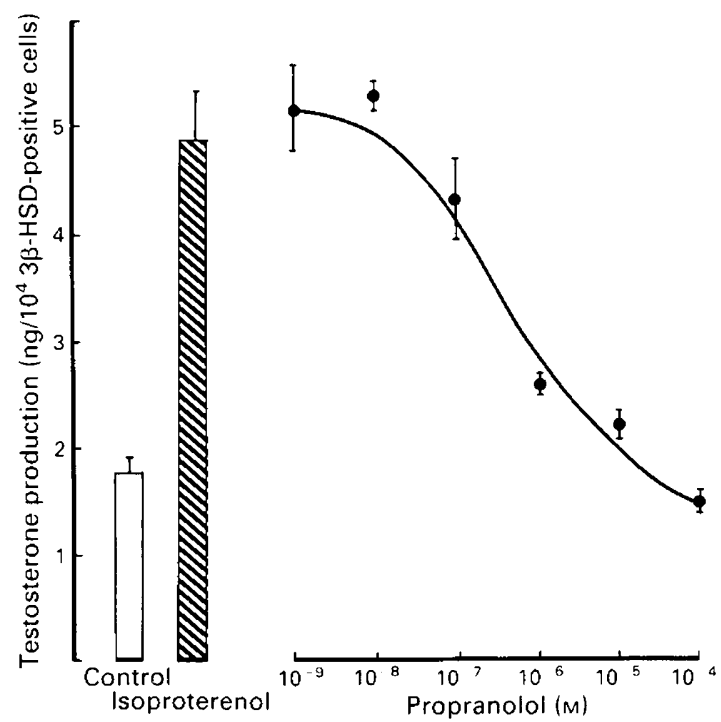

Fig. 3. Effect of propranolol on isoproterenol-stimulated testosterone production by fetal mouse Leydig cells in primary culture. Testosterone was measured in the medium after $3 \mathrm{~h}$ incubation with isoproterenol $\left(10^{-5} \mathrm{M}\right)$ in the presence of increasing concentrations of propranolol on Day 2 of culture. Results are the mean \pm s.e.m. of triplicate cultures and are representative of 2 experiments.

\section{Specificity of the catecholamine response}

The specificity of the $\beta$-adrenergic response was further investigated with two antagonists. As shown in Fig. 3, the stimulatory effect of isoproterenol on testosterone production was prevented in a dose-dependent manner by concomitant exposure of fetal Leydig cells to propranolol, a nonselective $\beta$-adrenergic antagonist. Half-maximum inhibition was observed for $4.5 \times 10^{-7} \mathrm{M}$ and a total abolition of isoproterenol-stimulated testosterone production with $10^{-4} \mathrm{M}$-propranolol. Due to the limited fetal material, the effect of phentolamine, a competitive $\alpha$-receptor antagonist, on the isoproterenol-stimulated testosterone production was investigated in a subsequent experiment. There were no significant differences in testosterone production between isoproterenol-stimulated cells with or without $10^{-4} \mathrm{M}$-phentolamine. The mean ( \pm s.e.m.) testosterone values (ng/10 $3 \beta$-HSD-positive cells) of quadruplicate cultures were $1.61 \pm 0.06$ in control, $2.66 \pm 0.23$ in the presence of isoproterenol and $2 \cdot 17 \pm 0.17$ in the presence of isoproterenol and phentolamine.

\section{Discussion}

The present study shows clearly that cathecolamines are able to stimulate the production of testosterone by fetal Leydig cells derived from testes of 18-day-old mouse fetuses. The ability of propranolol, a $\beta$-adrenergic antagonist, to block in a dose-dependent manner the stimulatory effect of isoproterenol and the lack of effect of the $\alpha$-antagonist, phentolamine, suggest that this effect is probably mediated via $\beta$-adrenergic receptors. These data confirm and extend reports (Anakwe $\&$ Moger, 1984; Pointis \& Latreille, 1986) that the fetal testis, like adult gonadal tissue (Cooke et al., 1982; Moger et al., 1982), can be directly affected by exposure to catecholamines.

It is unlikely that the response of fetal Leydig cells to catecholamines is due to an indirect effect of these agents on contaminant cells via their cAMP production. On the one hand the most likely 
contaminant cells (erythrocytes and fibroblasts) are unable to produce measurable amounts of cAMP in response to catecholamines (Jordan et al., 1978). On the other hand we have previously reported that large amounts of cAMP are necessary to induce a significant increase in testosterone production in such a preparation of fetal Leydig cells (Pointis \& Latreille, 1985). Moreover, the sensitivity of whole decapsulated fetal testis to isoproterenol was not higher than that observed in the present study with purified fetal Leydig cells, suggesting a lack of significant effect of the other cell type (Anakwe \& Moger, 1984). Lastly, the fact that, after $24 \mathrm{~h}$ in culture, maximum concentrations of catecholamines stimulate testosterone production with a potency slightly lower than that elicited with maximal hCG stimulation, indirectly suggests that both hormones most probably affect the same cell type. Taken together, these data therefore suggest that $\beta$-adrenergic stimulation of testosterone production is likely to be confined to Leydig cells.

The mechanism of development of catecholamine responsiveness during the culture period is presently unclear. Such an acquisition of the response to $\beta$-adrenergic agonist has been reported for different cell types such as hepatocytes (Nakamura et al., 1983), granulosa cells (Kliachko \& Zor, 1981 ) and Sertoli cells (Kierszenbaum et al., 1985). As shown in the current study, $\beta$-agonists did not affect or only slightly increased testosterone production in fresh interstitial cells derived from adult testis (Cooke et al., 1982; Moger et al., 1982). The fetus responds to direct stimuli such as asphyxia, hypoglycaemia or cold exposure with noradrenaline secretion (Comline et al., 1965; Eales \& Small, 1980). It is therefore possible that the stressful conditions for obtaining fetal material induced increased noradrenaline accumulation in the fetal bloodstream and subsequently results in a $\beta$-adrenergic desensitization. Such an hypothesis was, however, not confirmed with adult Leydig cells (Cooke et al., 1982; Moger \& Murphy, 1983). Whether the appearance of a $\beta$-adrenergic response during culture of fetal Leydig cells is due to synthesis of a new $\beta$-adrenergic receptor (Nakamura et al., 1983), altered differentiation (Moger \& Murphy, 1983) or other processes as suggested for adult cells is presently not clear.

High levels of catecholamines, from a fetal origin, have been measured in amniotic fluid and the fetal circulation (Ben-Jonathan \& Maxson, 1978). It is therefore tempting to speculate that in vivo these agents reach the fetal testis and exert a local regulation within the fetal testis. On the other hand, the presence of adrenergic axons innervating testicular interstitial tissue was reported for the adult (Goujard, 1954; Hodson, 1970; Lawrence \& Burden, 1976; Frankel \& Ryan, 1981). Such a direct involvement of the autonomic nervous system is likely to occur during fetal development since neural pathways innervating the fetal urogential complex have been characterized (Brauer $e t$ al., 1985).

In conclusion, although it is well established that $\mathrm{LH}$ is the main gonadotrophic hormone which controls testosterone synthesis in the fetal testis, the present observations that catecholamines stimulate testosterone production in vitro by fetal Leydig cells suggest that these $\beta$-adrenergic agents are also involved in the regulation of the fetal testicular function.

We thank Dr L. Cedard and Dr B. Rao for helpful advice and criticism of the text and Mrs M. Verger for typing the manuscript.

\section{References}

Anakwe, O.O. \& Moger, W.H. (1984) Ontogeny of rodent testicular androgen production in response to isoproterenol and luteinizing hormone in vitro. Biol. Reprod. 30, 1142-1152.

Anakwe, O.O., Murphy, P.R. \& Moger, W.H. (1985) Characterization of $\beta$-adrenergic binding sites on rodent Leydig cells. Biol. Reprod. 33, 815-826.

Ben-Jonathan, N. \& Maxson, R.E. (1978) Elevation of dopamine in fetal plasma and the amniotic fluid during gestation. Endocrinology 102, 649-652.
Brauer, M.M., Kanovich, S., Casanova, G. \& Sotelo, J.R. (1985) Development of the innervation of the urogenital complex in the fetal mouse. Experientia 41, 1605-1607.

Comline, R.S., Silver, I.A. \& Silver, M. (1965) Factors responsible for the stimulation of the adrenal medulla during asphyxia in the fetal lamb. J. Physiol., Lond. 178, 211-238.

Cooke, B.A., Golding, M., Dix, C.J. \& Hunter, M.G. (1982) Catecholamine stimulation of testosterone 
production via cyclic AMP in mouse Leydig cells in monolayer culture. Molec. cell. Endocr. 27, 221-231.

Eales, F.A. \& Small, J. (1980) Summit metabolism in newborn lambs. Res. vet. Sci. 29, 211-218.

Frankel, A.I. \& Ryan, E.L. (1981) Testicular innervation is necessary for the response of plasma testosterone levels to acute stress. Biol. Reprod. 24, 491-495.

Goujard, R. (1954) Contribution à l'étude des voies nerveuses sympatique du testicule. Archs Anat. microsc. Morph. exp. 43, 321-364.

Hodson, N. (1970) The nerves of the testis, epididymis and scrotum. In The Testis, vol. 1, pp. 47-09. Eds. A. D. Johnson, W. R. Gomes \& N. L. VanDemark. Academic Press, New York.

Jordan, A.W., III, Caffrey, J.L. \& Niswender, G.D. (1978) Catecholamine-induced stimulation of progesterone and adenosine $3^{\prime}, 5^{\prime}$-monophosphate production by dispersed ovine luteal cells. Endocrinology 103, 385-392.

Kierszenbaum, A.L., Spruill, W.A., White, M.G., Tres, L.L. \& Perkins, J.P. (1985) Rat Sertoli cells acquire a $\beta$-adrenergic response during primary culture. Proc. natn. Acad. Sci. U.S.A. 82, 2049-2053.

Kliachko, S. \& Zor, U. (1981) Increase in catecholaminestimulated cyclic AMP and progesterone synthesis in rat granulosa cells during culture. Molec. cell. Endocr. 23, 23-32.

Lawrence, I.E., Jr \& Burden, H.W. (1976) The autonomic innervation of the interstitial gland of the rat ovary during pregnancy. Am. J. Anat. 147, 81-94.

Moger, W.H. \& Murphy, P.R. (1983) $\beta$-adrenergic agonist induced androgen production during primary culture of mouse Leydig cells. Archs Androl. 10, 135-142.

Moger, W.H., Murphy, P.R. \& Casper, R.F. (1982) Catecholamine stimulation of androgen production by mouse interstitial cells in primary culture. $J$. Androl. 3, 227-231.
Nakamura, T., Tomomura, A., Noda, C., Shimoji, M. \& Ichihara, A. (1983) Acquisition of a $\beta$-adrenergic response by adult rat hepatocytes during primary culture. J. biol. Chem. 25, 9283-9289.

Pointis, G. \& Latreille, M.T. (1985) Regulation of testosterone production in Leydig cells from fetal mice under dynamic conditions: effect of human chorionic gonadotrophin and 8-bromo-cyclic AMP. J. Endocr. $107,409-414$.

Pointis, G. \& Latreille, M.T. (1986) Beta-adrenergic stimulation of androgen production by fetal mouse Leydig cells in primary culture. Experientia 42, 617-619.

Pointis, G. \& Mahoudeau, J.A. (1974) Etude de la production de testosterone par le testicule embryonnaire de souris en culture organotypique. C. r. hebd. Séance. Acad. Sci. Paris D 279, 1197-1200.

Pointis, G., Rao, B., Latreille, M.T. \& Cedard, L. (1984) Hormonal regulation of testosterone production in short-term primary culture of fetal mouse Leydig cells. J. Steroid Biochem. 20, 525-528.

Poyet, P. \& Labrie, F. (1983) Characterization of betaadrenergic receptors in dispersed rats Leydig cells. Biol. Reprod. 28 (Suppl. 1), Abstr. 59.

Zieher, L.M., Debeljuk, L., Iturriza, F. \& Mancini, R.E. (1971) Biogenic amine concentrations in testes of rats at different ages. Endocrinology 88, 351-354.

Zuspan, F.P., Behrman, R. \& Paton, J. (1974) Amniotic fluid epinephrine and norepinephrine. I. Comparison between the human and baboon. Am. J. Obstet. Gynecol. 118, 837-841. 